\title{
Financial Aspect Analysis in Business Feasibility Studies
}

\section{Analisis Aspek Keuangan dalam Studi Kelayakan Bisnis}

\author{
Nur Hidayah Pulungan 1); Dwi April Yani Simangungsong 2); Roza Hayadi 2); Suhairi 2) \\ 1,2) Fakultas Ekonomi Dan Bisnis Islam, Universitas Islam Negeri Sumatera Utara \\ Email: ${ }^{1)}$ nhp270701@gmail.com ; ${ }^{2)}$ Dwiaprilyanisss@gmail.com ; ${ }^{2)}$ Hayadyroza1@gmail.com ; ${ }^{2)}$ \\ suhairi@uinsu.ac.id
}

\section{How to Cite :}

Pulungan, N. H., Simangungsong, D. A. Y., Hayadi, R., Suhairi. (2021 Financial Aspect Analysis in Business Feasibility Studies. Jurnal Ekonomi Manajemen Akuntansi Dan Keuangan, 3(1). DOI: https://doi.org/10.53697/emak.v3i1

ARTICLE HISTORY

Received [22 Desember 2021]

Revised [30 Desember 2021]

Accepted [10 Januari 2022]

\section{KEYWORDS}

Financial Aspects, Business,

Business Feasibility Study.

This is an open access article under the $C C-B Y$-SA license

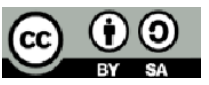

\section{ABSTRAK}

Artikel ini berisi tentang seperti apa sajakah aspek keuangan berpengaruh dalam kelayakan bisnis. Yang dimana seperti yang kita ketahui bahwa Aspek Keuangan merupakan salah satu aspek yang sangat sangat penting dalam berjalan nya bisnis yang akan di jalankan oleh pebisnis tersebut. Dan dalam makalah ini penulis akan meneliti di dala aspek keuangan apa saja yang perlu di perhatikan dan di analisis guna untuk kepentingan studi kelayakan bisnis tersebut untuk perkembangan bisnis tersebut.

\section{ABSTRACT}

This article contains about what financial aspects have an effect on business viability. Which as we know that the Financial Aspect is one aspect that is very very important in the running of the business that will be run by the businessman. And in this paper the author will examine what financial aspects need to be considered and analyzed in order to study the feasibility of the business for the development of the business.

\section{PENDAHULUAN}

Perkembangan bisnis di era global saat ini sudah pasti akan sangat menentukan para pebisnis untuk untuk merubah pola pikir mereka itu mengikuti trend saat ini guna untuk mengembangkan usahanya dan pertumbuhan badan usaha tersebut. Berdasarkan perkembangan perekonomian Indonesia, sejak tahun 2006 telah dicanangkan ekonomi kreatif dengan program Indonesia Design Power. Namun keputusan Instruksi Presiden Republik Indonesia tentang pengembangan ekonomi kreatif baru diterbitkan pada tahun 2009. Dalam Rini dan Czafrani (2010) menyatakan bahwa ekonomi kreatif mencakup segala aspek yang bertujuan meningkatkan daya saing dengan menggunakan kreatifitas individu dari skala ekonomi. Menurut kementerian perindustrian“pertumbuhan ekonomi kreatif di indonesia setiap tahunnya meningkat sekitar tujuh persen, dan penyumbang nilai tambah tertinggi pada sektor ekonomi kreatif adalah subsektor kerajinan, fashion dan kuliner" (Munawaroh, 2017:2).

Perkembangan ekonomi kreatif mendorong setiap pelaku usaha untuk menyajikan produk yang memiliki daya saing tinggidan iconic sebagai nilai tambah dari produk tersebut. Suatu bisnis yang didirikan tidak serta merta berdiri hanya dengan spekulasi akan memperoleh keuntungan, melainkan perlu adanya sebuah analisis tentang kelayakan dari bisnis yang akan dijalankan.

Analisis kelayakan bisnis berfungsi sebagai filter untuk menentukan apakah sebuah ide bisnis layak dilanjutkan. Fungsi utamanya adalah sebagai alat penyelidikan bisnis (Wijatno, 2009). Pada awal perencanaan pendirian sebuah bisnis diperlukan adanya rencana keuangan. Rencana 
keuangan memberi pengusaha sebuah gambaran lengkap mengenai bagaimana dan kapan dana datang dalam usaha, untuk apa dana dikeluarkan, berapa banyak jumlah kas tersedia dan posisi keuangan yang diproyeksikan (Hisrich, 2008:378). Perencanaan keuangan yang bagus merupakan salah satu unsur atau pun aspek yang dapat mempengaruhi perkembangan bisnis yang tengah dijalani oleh para pebisnis. Dari beberapa penjelasan diatas maka dalam hal ini penulis tertarik untuk meneliti tentang "Analisis Aspek Keuangan Dalam Studi Kelayakan Bisnis".

\section{LANDASAN TEORI}

\section{Studi Kelayakan Bisnis}

Studi kelayakan bisnis menurut (Umar, 2009) adalah penelitian terhadap rencana bisnis yang tidak hanya menganalisis layak atau tidak layak bisnis dibangun, tetapi juga saat dioperasionalkan secara rutin dalam rangka pencapaian keuntungan yang maksimal untuk waktu yang tidakditentukan.

Tujuan yang hendak dicapai dari konsep studi kelayakan bisnis menurut (Sofyan, 2003), yaitu :

1. Bagi pihak investor : Studi kelayakan bisnis ditujukan untuk melakukan penilaian kelayakan terhadap suatu usaha atau proyek untuk membuat suatu keputusan investasi, karena sudah dikaji dari berbagai aspek. Seperti aspek pasar, aspek teknis dan operasi, aspek organisasi dan manajemen, aspek lingkungan dan aspekfinansial.

2. Bagi analisis : Studi kelayakan bisnis ini adalah alat yang digunakan untuk menunjang kelancaran tugas-tugas dalam melakukan penelitian terhadap suatu usaha baru, pengembangan usaha atau untuk menilai kembali usaha yang sudahberjalan.

3. Bagi masyarakat : Studi kelayakan bisnis dapat menjadi peluang untuk meningkatkan kesejahteraan dan perekonomian rakyat, secara langsung maupun yang muncul akibat adanya nilai tambah sebagai akibat dari adanya suatu usaha atauproyek.

4. Bagi pemerintah : Dari sudut pandang mikro, hasil dari studi kelayakan ini bagi pemerintah terutama untuk tujuan pengembangan sumberdaya baik dalam pemanfaatan sumber-sumber alam maupun pemanfaatan sumberdaya manusia, berupa penyerapan tenaga kerja, selain itu, adanya usaha baru atau berkembangnya usaha lama sebagai hasil dari studi kelayakan bisnis yang dilakukan oleh individu atau badan usaha tentunya akan menambah pemasukan pemerintah baik dari pajak pertambahan nilai (PPN) maupun dari pajak penghasilan (PPH) dan retribusi berupa biaya perizinan, biaya pendaftaran dan administrasi, dan lainnya yang layak diterima sesuai dengan ketentuan yang berlaku. Secara makro, pemerintah dapat berharap dari keberhasilan studi kelayakan bisnis ini adalah untuk mempercepat pertumbuhan ekonomi daerah ataupun nasional, sehingga tercapai pertumbuhan PDRB dan kenaikan income perkapita.

\section{Aspek-Aspek Yang Harus Dipertimbangkan Dalam Melakukan Studi Kelayakan Bisnis}

Ada beberapa aspek yang harus diperhatikan dalam studi kelayakan bisnis yaitu guna untuk mengetahui kelayakan bisnis tersebut yang dimana aspek-aspek dalam studi kelayakan bisnis yaitu diantaranya:

1. Aspek pasar dan pemasaran.

2. Aspek teknis dan teknologi.

3. Aspek sumber daya manusia dan manajemen.

4. Aspek keuangan.

5. Aspek Keuangan dalam Analisis KelayakanBisnis

6. Pada pembahasan kali ini penulis akan membahas tentang analisis aspek keuangan dalam studi kelayakan bisnis

\section{Analisis Aspek Keuangan Pada Studi Kelayakan Bisnis}

222 | Nur Hidayah Pulungan, Dwi April Yani Simangungsong, Roza Hayadi, Suhairi; Financial Aspect... 
1. Aspek Keuangan. Aspek keuangan pada studi kelayakan bisnis digunakan untuk menilai keuangan perusahaan yang meliputi, perolehan sumber dana, estimasi pendapatan dan jenis investasi beserta biaya yang dikeluarkan selama investasi serta proyeksi laporan keuangan yang terdiri dari laporan laba rugi, neraca dan arus kas. Dari aspek keuangan tersebut dapat diberikan penilaian apakah sebuah usaha dapat dinyatakan layak atau tidak untuk dijalankan dengan beberapa alat analisis (Kasmir \& Jakfar, 2004). Aspek-aspek Dalam Keuangan yaitu diantaranya:

2. Perkiraan Dalam Biaya Investasi. Penanaman modal atau yang sering disebut investasi didefenisikan sebagai pemilikan sumber-sumber jangka panjang yang akan bermanfaat pada beberapa periode akuntansi yang akan datang (Supriyono, 1987).

Dalam bagian ini yang perlu disajikan adalah mengenai jenis pengeluaran investasi dan jumlah dana yang diperlukan untuk mendirikan suatu usaha. Penyajian dapat dilakukan dalam bentuk table. Harga-harga dari barang-barang investasi yang digunakan hendaknya sesuai dengan harga pada saat pengadaan investasi untuk menghindari penyimpangan dalam perhitungan. Contoh pengeluaran untuk investasi dalam usaha peternakan antara lain: biaya pembangunan kandang, gudang, dan bangunan lainnya, biaya pembelian calon induk, biaya pembelian mesin dan peralatan, kendaraan, instalasi listrik dan air, biaya pembelian lahan atau sewa jangka panjang, dan lain sebagainya. Berkaitan dengan barang-barang investasi tersebut juga perlu disampaikan mengenai umur ekonomis barang investasi, serta nilai penyusutannya.

Menurut (Mulyadi, 2001) mendefinisikan investasi sebagai pengkaitan sumber-sumber dalam jangka panjang untuk menghasilkan laba di masa yang akan datang. Investasi ini dibagi menjadi empat golongan, yaitu:

Investasi yang tidak menghasilkan laba (non-profit investment). Investasi jenis ini timbul karena adanya peraturan pemerintah atau karena syarat-syarat kontrak yang telah disetujui, yang mewajibkan perusahaan untuk melaksanakannya tanpa pertimbangan laba atau rugi.

Investasi yang tidak dapat diukur labanya (non-measurable profitinvestment). Investasi ini dimaksudkan untuk menaikkan laba, namun laba yang diharapkan diperoleh perusahaan dengan adanya investasi sulit untuk dihitung secara teliti.

Investasi dalam penggantian ekuipmen (replacement investment). Investasi jenis ini meliputi pengeluaran untuk penggantian mesin dan peralatan yang ada. Informasi penting yang perlu dipertimbangkan dalam keputusan penggantian mesin dan peralatan adalah informasi akuntansi diferensial yang berupa aktiva diferensial dan biaya difenrensial.

Investasi dalam perluasan usaha (expansion investment) Investasi jenis ini merupakan pengeluaran untuk menambah kapasitas produksi atau operasi menjadi lebih besar dari sebelumnya.

\section{Biaya Modal}

Biaya modal menurut (Sundjaja, Drs., MSBA. \& Barlian, Ak., M.Sc., 2003) didefenisikan sebagai tingkat pengembalian yang harus dihasilkan oleh perusahaan atas investasi proyek untuk mempertahankan nilai pasar sahamnya. Biaya modal dapat juga dianggap sebagai tingkat pengambalian yang diingkan oleh penyandang dana untuk menenamkan dananya ke dalam perusahaan.

Biaya modal menurut (Umar, 2009) dimaksudkan untuk menentukan berapa besar biaya riil dari masing-masing sumber dana yang dipakai dalam berinvestasi. Perlu untuk mementukan biaya penggunaan modal rata-rata dari keseluruhan dana yang akan dipakai, sehingga berdasarkan hal ini patokan tingkat keuntungan yang layak dari proyek bisnis dapat diketahui.

\section{Peramalan}

Menurut Render dan Heizer (2001) peramalan adalah seni dan ilmu memprediksi peristiwaperistiwa masa depan. Peramalan memerlukan pengembilan data historis dan memproyeksikannya ke masa depan dengan beberapa bentuk model matematis. 
Dalam peralaman ada tujuh langkah sistem yang perlu diperhatikan, yaitu:

1. Menentukan penggunaan dari peramalan

2. Memilih barang yang akandiramalkan

3. Menentukan horizon waktu dari peramalan

4. Memilih modelperamalan

5. Mengumpulkan data yang diperlukan untuk membuat peramalan

6. Membuat peramalan

7. Memvalidasi dan mengimplementasikan hasilnya

Terdapat beberapa metode peramalan yang dapat digunakan untuk melakukan peramalan, diantaranya :

Pendekatan awam : Model peramalan yang paling efektif dalam biaya dan tujuan yang efisien. Sedikitnya metode ini menyediakan poin permulaan di mana merupakan model yang lebih canggih yang kemudian dapatdibandingkan.

Pergerakan rata-rata : Metode yang menggunakan sejumlah nilai data aktual historis untuk menghasilkan peramalan. Pergerakan rata-rata bermanfaat jika kita dapat mengasumsikan bahwa permintaan pasar akan tetap kokoh secara wajar selama bertahun-tahun.

Penghalusan eksponensial : Metode peramalan pergerakan rata- rata bobot lainnya. Ini melibatkan sangat sedikit catatan yang mempertahankan data masa sebelumnya dan mudah untuk digunakan secara wajar.

\section{METODE PENELITIAN}

Dalam penelitian ini penulis menggunakan metode penelitian kualitatif, beberapa pendapat dari sudut pandang penulis, serta kajian literatur, pendapat para ahli, dan juga beberapa dukungan dari hasil penelitian sebelumnya, yang dimana guna untuk melengkapi materi dan juga mencari tau tentang seperti apakah "Analisis Aspek Keuangan Dalam Studi Kelayakan Bisnis"

\section{HASIL DAN PEMBAHASAN}

Munurut (Ikatan Akuntansi, 2009) pendapatan adalah penghasilan yang timbul selama dalam aktivitas normal entitas dan dikenal dengan bermacam-macam sebutan yang berbeda seperti penjualan, penghasilan jasa (fees), bunga, dividen dan royalti. Dalam PSAK No.23 pendapatan didefenisikan sebagai arus masuk bruto dari manfaat ekonomi yang timbul dari aktivitas normal perusahaan selama satu periode bila arus masuk itu mengakibatkan kenaikan ekuitas, yang tidak berasal dari kontribusi penaman modal. Pendapatan timbul dari transaksi dan kejadian sebagai berikut :

Penjualan barang, meliputi barang yang diproduksi oleh entitas untuk dijual dan baranga yang dibeli untuk dijual kembali, seperti barang dagang yang dibeli pengecer atau tanah dan properti lain yang dimiliki untuk dijualkembali. Penjualan jasa, biasanya terkait dengan kinerja entitas atas tugas yang telah disepakati secara kontraktual untuk dilaksanakan selama satu periode waktu. Jasa tersebut dapat diserahkan dalam satu periode atau lebih dari satuperiode.

Penggunaan entitas oleh pihak lain menimbulkan pendapatan dalam bentuk: (a) bunga yaitu membebankan untuk penggunaan kas atau setara kas, atas jumlah terutang kepada entitas; (b) royalti yaitu pembebanan untuk penggunaan aset jangka panjang entitas, misal paten, merek dagang, hak cipta, dan peranti lunak komputer; dan (c) dividen yaitu distribusi laba kepada pemegang investasi ekuitas sesuai dengan proporsi kepemilikan meraka atas kelompok modaltertentu. 
Menurut Carter (2009) biaya didefenisikan sebagai alat tukar, pengeluaran, atau pengorbanan yang dilakukan untuk menjamin perolehan manfaat. Dalam akuntansi keuangan, pengeluaran atau pengorbanan pada tanggal akuisisi dicerminkan oleh penyusutan atas kas atau aset lain yang terjadi pada saat ini atau di masa yang akan datang.

Menurut (Hansen \& Mowen, 2009) perilaku biaya adalah istilah umum untuk mendiskripsikan apakah biaya berubah seiring dengan perubahan keluaran. Biaya-biaya bereaksi pada perubahan keluaran dengan berbagai cara. Berikut adalah klasifikasi aktivitas yang mempengaruhi keluaran :

1. Biaya tetap. Biaya tetap didefenisikan sebagai biaya yang dalam jumlah keseluruhan tetap konstan dalam rentang yang relevan ketika tingkat keluaran aktivitas berubah.

2. Biaya variabel. Biaya variabel didefenisikan sebagai biaya yang dalam jumlah keseluruhan bervariasi secara proporsional terhadap perubahan keluaran.

3. Biaya campuran. Biaya campuran atau biaya semivariabel didefenisikan sebagai biaya yang memiliki komponen biaya tetap dan variabel.

Laporan arus kas disusun untuk menunjukkan perubahan kas selama periode tertentu serta memberikan alasan mengenai perubahan kas tersebut dengan menunjukkan dari mana sumber kas dan pengunaannya. Penerimaan dan pengeluaran kas ada yang bersifat rutin dan juga ada pula yang bersifatinsidental.

Menurut (Umar, 2009) kas merupakan aktiva yang paling likuid atau merupakan salah satu unsur modal kerja yang paling tinggi likuiditasnya. Aliran kas dikelompoknya menjadi tiga bagian, yaitu :

1. Aliran kas permulaan (initial cashflow). Aliran kas permulaan yang berhubungan dengan pengeluaran untuk investasi.

2. Aliran kas operasional (operational cashflow). Aliran kas yang biasanya mempunyai selisih neto yang positif yang dapat dipakai untuk mencicil pengembalian investasinya.

3. Aliran kas terminal (terminal cashflow). Aliran kas dari nilai aktiva tetapyangdianggap sudah tidak mempunyai nilai ekonomis lagi dan pengembalian modal kerja awal.

Break Event Point (BEP) atau Titik Impas merupakan suatu keadaan perusahaan yang tidak untung tapi juga tidak rugi, dimana total revenue sama dengan total biaya. Analisis Break Even Point ini dapat dilihat dari tiga hal antara lain : jumlah produksi, tingkat harga produk, dan waktu pengembalian biaya.

Melalui analisis Break Even Point berdasarkan jumlah produksi, dapat diketahui padajumlah produksi berapa perusahaan tidak perusahaan tidak untung tapi juga tidak rugi. Dengan mengetahui titik tersebut dapat ditentukan jumlah produksi yang dapat menghasilkan profit.

Melalui analisis Break Even Point berdasarkan harga produk, dapat diketahui pada harga produk berapa perusahaan tidak untung tapi juga tidak rugi. Dengan mengetahui titik tersebut dapat ditentukan harga produk yang dapat menghasilkan profit. Artinya jika harga BEP sebesar A rupiah, maka jika harga di atas $A$ perusahaan sudah untung, dan sebaliknya akan rugi jika harga produk di bawah $\mathrm{A}$.

Tingkat BEP dilihat dari segi waklu, maksudnya untuk mengetahui berapa lama usaha yang direncanakan bam dapat menutupi segala biaya yang dikeluarkan. Ukuran ini sangat penting diketahui, karena terlalu lama waktu mengembalikan total biaya belum tentu layak bagi semua pengusaha/investor kendatipun usaha ini layak berdasarkan criteria investasi. Semakin cepat waktu pengembalian total biaya maka akan semakin layak/feasible usaha yang direncanakan tersebut.

Khusus bagi usaha/bisnis yang bergerak dalam bidang produksi maka analisis Pay Back Period sangat penting dilakukan. Pay Back Period merupakan suatu jangka waktu yang diperlukan untuk dapat mengembalikan semua biiya investasi yang telah dikeluarkan. Semakin singkat waktu yang diperlukan untuk dapat mengembalikan semua biaya investasi semakin baik atau layak usaha yang direncanakan tersebut, dan sebaliknya. Karena jumlah investasi yang telah dikembalikan akan dapat digunakan untuk investasi bam atau usaha lain yang juga dapat menghasilkan profit, atau dapat juga digunakan untuk mengembangkan usaha yang sudah ada. Cepatnya perkembangan 
teknologi seringkali menyebabkan suatu teknologi yang digunakan oleh suatu perusahaan secara ekonomis sudah tidak layak walaupun secara teknis masih baik, karena perusahaan lain yang sejenis sudah menggunakan teknologi baru yang lebih ekonomis. Untnk mampu bersaing, maka perusahaan tersebut harus mengikuti menggunakan teknologi baru tersebut, dengan mengganti teknologi yang lama dengan yang baru.

\section{KESIMPULAN DAN SARAN}

Aspek Keuangan merupakan salah satu aspek yang sangat penting sebelum kita memulai bisnis, ayng dimana seperti yang kita ketahui bahwa Aspek keuangan pada studi kelayakan bisnis digunakan untuk menilai keuangan perusahaan yang meliputi, perolehan sumber dana, estimasi pendapatan dan jenis investasi beserta biaya yang dikeluarkan selama investasi serta proyeksi laporan keuangan yang terdiri dari laporan laba rugi, neraca dan arus kas. Dari aspek keuangan tersebut dapat diberikan penilaian apakah sebuah usaha dapat dinyatakan layak atau tidak untuk dijalankan dengan beberapa alat analisis (Kasmir \& Jakfar, 2004).

Karena Bagi perusahaan yang direncanakan dengan orientasi profit, aspek ini sangat penting untuk disajikan. Dalam menyusun studi kelayakan bisnis, hal-hal yang perlu diuraikan dalam bagian ini antara lain: biaya investasi, biaya operasi dan pemeliharaan, kebutuhan modal kerja, sumber pembiayaan, perkiraan pendapatan, perhitungan criteria investasi. Disamping itu perlu juga diuraikan mengenai kondisi break point, beserta pay back period, proyeksi laba (rugi), proyeksi aliran kas, dan dampak usaha terhadap perekonomian masyarakat secara keseluruhan.

\section{DAFTAR PUSTAKA}

H.M. Yacob Ibrahim. 2003. Studi Kelayakan Bisnis. Edisi Revisi. Rineka Cipta.

Kasmir dan Jakfar. 2012, Studi Kelayakan Bisnis. Cetakan Kedelapan, Kencana, Jakarta.

Lilis Sulastri. 2016. Studi Kelayakan Bisnis Untuk Wirausaha. LGM - LaGood's Publishing.

Abdullah.HM. Ma'ruf. 2017, Studi Kelayakan Bisnis, Cetakan 1, Aswaja Pressindo, Yogyakarta.

Sunyoto Danang. 2014. Studi Kelayakan Bisnis. Yogyakarta: CAPS (Center of Academic Publising Sevice).

Jumingan. 2014. Studi Kelayakan Bisnis. Teori dan Pembuatan Proporsal Kelayakan. Bumi Aksara. Jakarta.

Kasmir dan Jakfar. 2014, Studi Kelayakan Bisnis. Edisi Revisi, Prenadamedia Group, Jakarta.

Purwana. D., Hidayat. N. 2017, Studi Kelayakan Bisnis, Cetakan ke 2, PT Raja grafindo Persada, Depok.

Ibrahim, Yacob. 2009. Studi Kelayakan Bisnis. Jakarta: PT Rineka Cipta. Johan, Suwinto. 2011. Studi Kelayakan Pengembangan Bisnis. Yogyakarta: Graha.

226 | Nur Hidayah Pulungan, Dwi April Yani Simangungsong, Roza Hayadi, Suhairi; Financial Aspect... 